Int. J. Morphol.,

27(2):317-325, 2009.

\title{
Carbonated Water and Necro-Apoptotic Cell Death in Chicken Embrio Low Limb
}

\author{
Agua Carbonatada y la Muerte Celular por Necro-Apoptosis en Miembro Inferior de Embrión de Pollo \\ Marco Álvarez \& Lourdes Perdomo
}

ÁLVAREZ, M. \& PERDOMO, L. Carbonated water and necro-apoptotic cell death in chicken embrio low limb. Int. J. Morphol., 27(2):317-325, 2009.

SUMMARY: Carbonated water is a fundamental part of many drinks and its effects have been studied in many pathological situations. However, cells and tissue damage as a consequence of carbonated water has not been the subject of extensive research. We assessed the short-term effects of soda on in vitro Hanging-drop culture of myoblasts and ex vivo lower limb of 8-day-old chicken embryo skeletal muscle tissue. Several groups were designed: a) Control (Con-tyr), b) Carbonated water (Car), c) Coffe (Caf), and d) Cola beverage (Glu). The samples were observed with light microscopy and digital imaging analysis was performed. The ultra-structure of control and treated tissue were observed with electron microscopy. Immunohistochemistry techniques, such as terminal deoxynucleotidyl transferase-mediated dUTP nick- end labeling (TUNEL), TACTS Blue Label (TdT Kits) of R\&D Systems were used. The myoblasts monolayers treated with soda showed plenty of eosinophilics elements. The eosinophily corresponds to higher percentage of cell death. The muscular tissue of the low limb treated with carbonated water (Car) showed calcium phosphate and collagen decreases, 53,86\% and $82,95 \%$ respectively and enlarged nuclei of a higher size, with an evident loss of the parallel arrangement and fragmented nuclei. Compared to control samples, the muscular disorganization was accompanied by a positive reaction of the apoptotic bodies on TACS, also a positive reaction to ApopTacg and another positive reaction for the metalloproteases in the inter fibrillar cartilage matrix. These changes were not significant in Tyrode's solution controls, Coffee and Cola beverage groups. The morphological outcome can be apoptosis, necrosis or a mixed phenotype, suggesting that the carbonated water toxic effect might be related to these cell death processes. Further research, exploring biochemical factors will be required to elucidate necro-apoptotic cell death induced by carbonated water.

KEY WORDS: Soda Club; Chicken embryo; Low limb; Apoptosis; Necrosis.

\section{INTRODUCTION}

Carbonated water is a fundamental part of many drinks that in the last decades have experimented a considerably consumption increase in a worldwide level. All this without taking into consideration the various pathologies it can entail (Wyshak, 2000). Among the pathologies associated to the consumption of carbonated water we have those related to the osseous system, specially the osseous demineralization that generates fractures in children, young people and physically active women (Wyshak \& Frisch, 1994). A high damage in the dentin, enamel and pulp in young people's teeth with a high intake of carbonated water has also been reported (Harding, 2003). In spite of the great number of pathologies registered and linked to carbonated water, as far as we know, the tissular and cellular reactions to the toxic effect of this chemical agent are not clearly established. It is noteworthy to mention, that in osseous pathologies with a non-chemical-origin etiology like the severe osteochondral damage and posttraumatic arthritis, the relation between the apoptosis signs and the degradation of the cartilagenosic matrix into chondrocytes has been already proved (Costouros et al., 2004; Borrelli, 2006). Many studies of osseous pathologies with a non-chemical-origin etiology, in which it has been reported that the related tissular damage is linked to events that lead to cell death, have already been carried (Morel et al., 2006). Based on this evidence it would be necessary to ask if a possible reaction to the toxic effect of artificially carbonated water could be related to cell death events such as necrosis, apoptosis or a combination of both. In this paper it was used "in vitro" chicken embryo muscular tissue and "ex vivo" chicken embryo low limb as experi-

Sección de Microscopia Electrónica, Instituto Anatómico José Izquierdo, Facultad de Medicina Universidad Central de Venezuela. http://www.med.ucv.ve/ IA/SecMicElec.htm.

Project financed by CDCH-UCV. Project No PI-09-00-6011-2005 
mental models to evaluate the toxic effect of carbonated water. The chicken embryo low limb shows three clearly distinguishable portions, or tissular regions: a hyaline and muscular one, with an intermediate, of fibrous nature, which corresponds to the periosteal collar between them. This makes the structural and ultrastuctural characterization of the respective components possible.

\section{MATERIAL AND METHOD}

In vitro chicken embryo muscular tissue. Muscular tissue explants from 8-day-old chicken embryo low limbs (Hamburger \& Hamilton, 1992) were cultivated to obtain 24-hour myoblasts monolayers through the hanging drop method (Alvarez et al., 2007). The 24-hours in vitro myoblasts monolayers were chosen randomly and organized into 4 groups: a) Control (Con-tyr), b) artificially carbonated water, 6gr/l (Car) from a commercial Soda Club, $\mathrm{pH} 3,4, \mathrm{c})$ carbonated water + caffeine, $1 \%$ (Caf) and d) Cola beverage, $50 \mathrm{mg} / \mathrm{ml}$ (Glu). These groups were treated for one hour (1h) at $37^{\circ} \mathrm{C}$. All cultures were stained with haematoxilyn-eosin (HE). Digital representative images were obtained to evaluate the percentage of cell death population of cultivated myoblasts through multiple observations of the culture's different areas. All the measurements were expressed as the medium value \pm standard error. The ANOVA statistics test was used to compare the medium values. The values $* \mathrm{p}<0.05$ were considered statistically significant. ImajeJ® version 1.36 and Adobe Photoshop ${ }^{\circledR}$ were used for the capture and analysis of digital images. The number of pixels (y) and the gray intensities 0-241 (x) were used to generate the respective histograms.

Ex vivo chicken embryo low limb. A total of 12 8-day-old chicken embryo low limbs were removed by dissection and kept "ex vivo", and organized randomly into two groups, control and treated. The control samples were immersed in a Tyrode solution and the treated samples were incubated in Soda Club (Car). Both groups of samples were kept at $37^{\circ} \mathrm{C}$ for one hour (1h).

\section{Chicken embryo low limb micro-architecture}

Structure. Once the time of the treatment was over, the low limbs (control and treated) were chosen again randomly. A subgroup of each of them was fixed in formol-zinc, dehydrated in isopropyl alcohol $(50 \%, 70 \%, 85 \%, 100 \%)$ dealcoholized in xilol, infiltrated and embedded in paraffin. Five-micron histological sections, from longitudinally oriented samples were made. The samples were stained with hematoxylin \& eosin (HE). Calcium phosphate's deposits and collagen fibers inside the intermediate portion, between the hyaline and he muscular ones, were treated with Von Kossá reaction and Gomori's one step trichrome stain respectively. Using the calculation of the surface area through the analysis of the limiting borders between the hyaline and the muscular portion, the images of the low limb longitudinal pieces, the control and treated ones, allowed us to determine the spatial distribution of calcium phosphates and collagen matrix. For this purpose, a gray scale intensity threshold for each of the histochemical stainings and for each microscopic area, or illuminated and selected area was established. Each area was the same for control and treated samples. The digital images were captured using Nikon Microscope (40x and 20x objective), with a U-CMAD-2 Olympus camera. Eight-bit monochrome-digitized images (García et al., 2005; Shotton, 1998) of the myoblasts culture and tissue were used.

Ultrastructure. Hyaline and muscular portion's ultrastructural characteristics were described using the electronic transmission microscopy (TEM). To this end a second group on samples, control and treated, were fixed in Karnovsky (glutaraldehide 25\%, fomaldehide $37 \%$ in Millonig solution $0.2 \mathrm{M}, 320 \mathrm{mOsmol}, 7,4 \mathrm{pH}, 2$ hours, $4^{\circ} \mathrm{C}$ ) and post-fixed in Osmiun Tetroxide $2 \% 1$ hour, $4^{\circ} \mathrm{C}$. For its processing and observation in the Hitachi-500 electronic microscope the samples were dehydrated in acetone $(50 \%, 70 \%, 80 \%, 95 \%$ and $100 \%$ ) included in epoxic Araldite resin and 30-100nm thick sections were made. The sections were placed over a cooper grill and contrasted with uranil acetate $3 \%\left(60^{\circ} \mathrm{C}\right.$, $\left.45^{\prime}\right)$ and lead citrate (15').

Inmunohistochemistry. The TUNEL technique was used to determine the apoptosis trough in situ detection of the DNA fragmentation. The samples, control and treated, longitudinally oriented in paraffin sections, were rehydrated and immersed in buffer PBS at room temperature and preincubated in proteinase $\mathrm{K} 5 \mu \mathrm{l}$. The procedure to determine the apoptotic bodies was followed according to the Kit TACS blue Label indications (R\&D System) and Kit ApopTacg (Chemicon). To evaluate the distribution of the possible catabolic biomarkers that illustrate the alterations of the collagen matrix the monoclonal anti-human MMP-1 was used (Chemicon), in a 1:200 dilution. Detection and enlargement of inmunoperoxidase, avidine-biotine (Chemicon) diaminobenzidine (DAB) system was applied.

\section{RESULTS}

In vitro. Photographic evidence of the myoblasts monolayers from the low limb muscular tissue of the chicken embryo shows the effect of the Soda Club (Car), on the cellular 

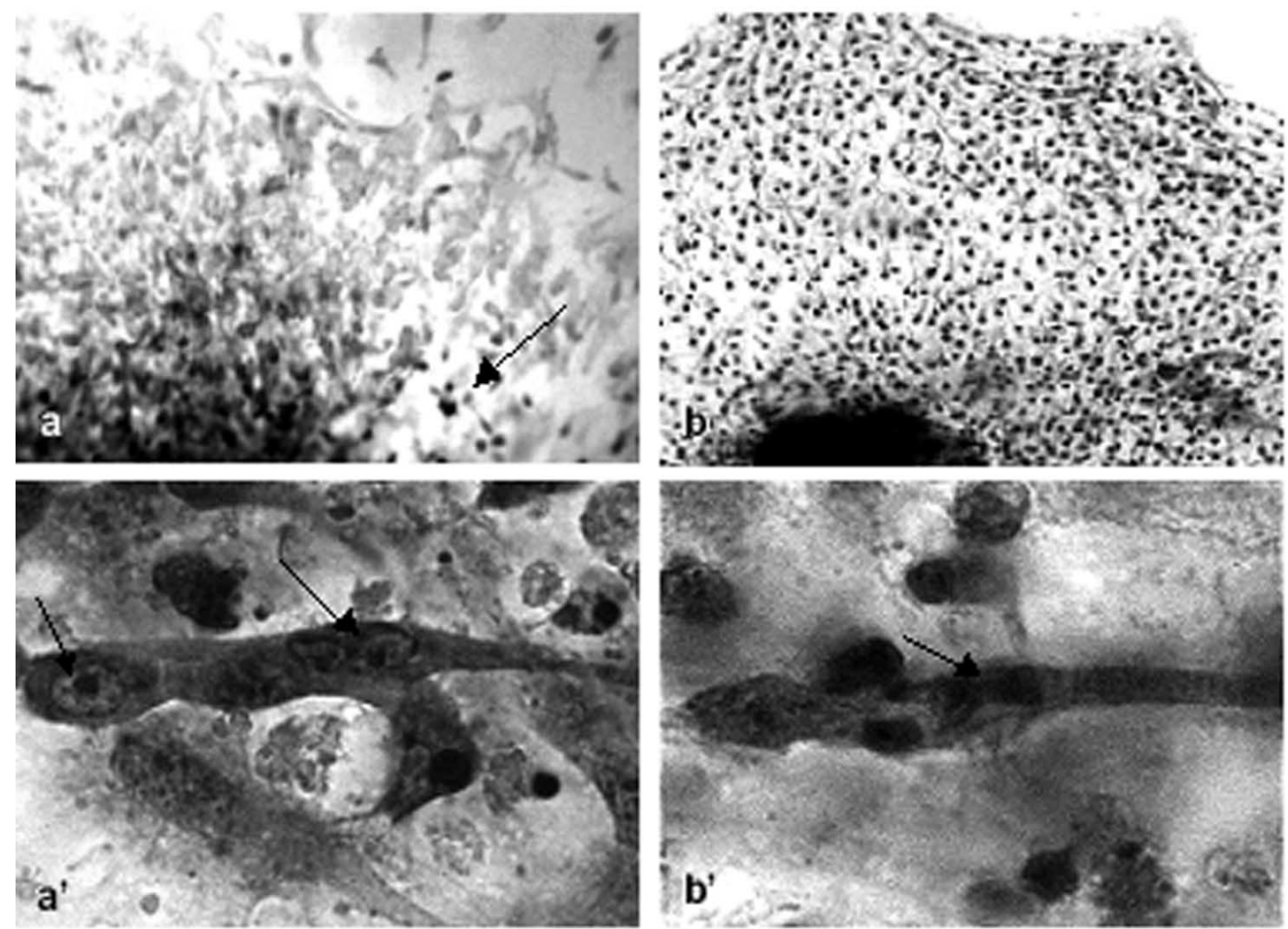

Fig.1 Eight-bit monochromedigitized images of the myoblasts monolayers from the low limb muscular tissue of the chicken embryo, 2448 x 3264 pixels in size. a) Control (Con-Tyr), b) Soda Club (Car), c) Caffeine (Caf) and c) Cola beverage (Glu).
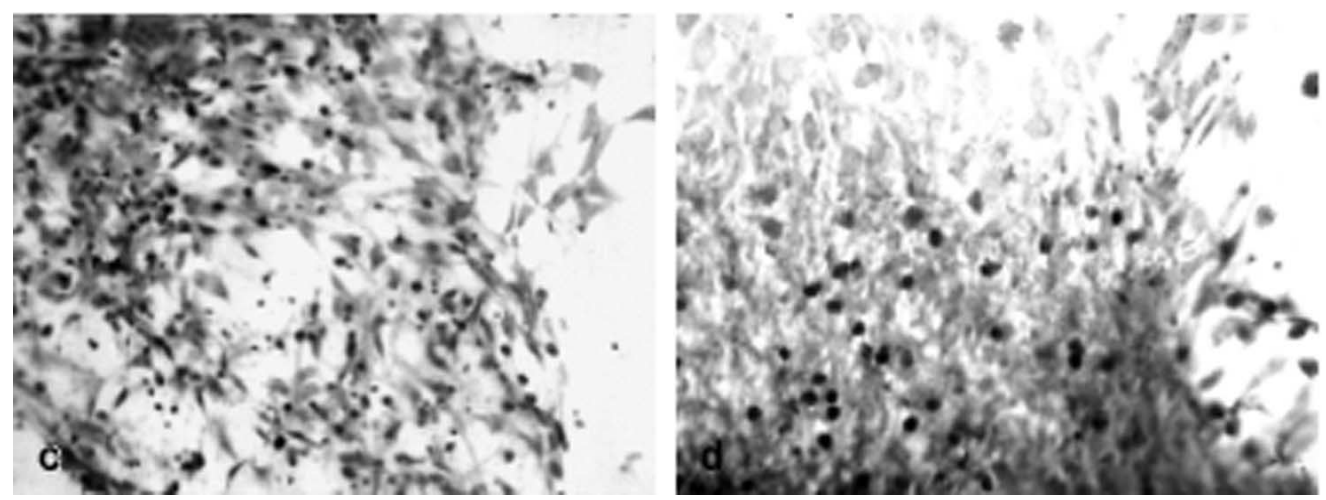

population, contrasting the Control (Con-tyr), sample to the respective treatments (Fig. 1). The cellular population that represents the Control (Fig. 1a) shows an area of homogeneous growth with few cellular eosinophilic elements (arrow). In contrast to the myoblasts monolayers treated with Soda Club (Car), (Fig. 1b) in which we can see plenty of eosinophilics elements or dead cells. At high magnification it is possible to observe early formed muscular fibers. Control (Fig 1a') shows long fibers with clear nucleus and nuclei. In contrast to the Soda Club (Car) where the nucleus are dense and the nucleolus are not clearly visible (Fig. 1b'). It is noteworthy to point out that in the samples treated with caffeine (Caf) and with Cola beverage (Glu) there were less of these cellular elements (Fig. 1c, Fig. 1d). The plenty eosinophilic bodies observed in the cellular population are represented with gray-level-histogram (Fig. 2), terms which correspond to the monochrome-digitized images of the con- trol and treated myoblasts samples. The histograms obtained correspond to those emitted by the shiny images in which the gray levels are displaced to the light zone of the gray scale, particularly between 81 and 241. All the histograms obtained presented a similar tendency to this zone. However, compared to Control (Con-tyr) (Fig. 2a), the histograms of the samples treated with Soda Club (Car), show more dark tonalities (Fig. 2b). It differs from the samples treated with caffeine (Caf) (Fig. 2c) and Cola beverage (Glu) (Fig. 2d). The correlation between gray and black is different between Control (Con-Tyr), and the sample treated with Soda Club (Car). The higher percentage of dead cells (Fig. 3) correspond to the myoblasts population treated with Soda Club (Car) compared to the caffeine group ( $\mathrm{Caf}$ ) and Cola beverage (Glu) and Control (Con-tyr).

Ex vivo. The chicken embryo low limb's micro-architecture, 

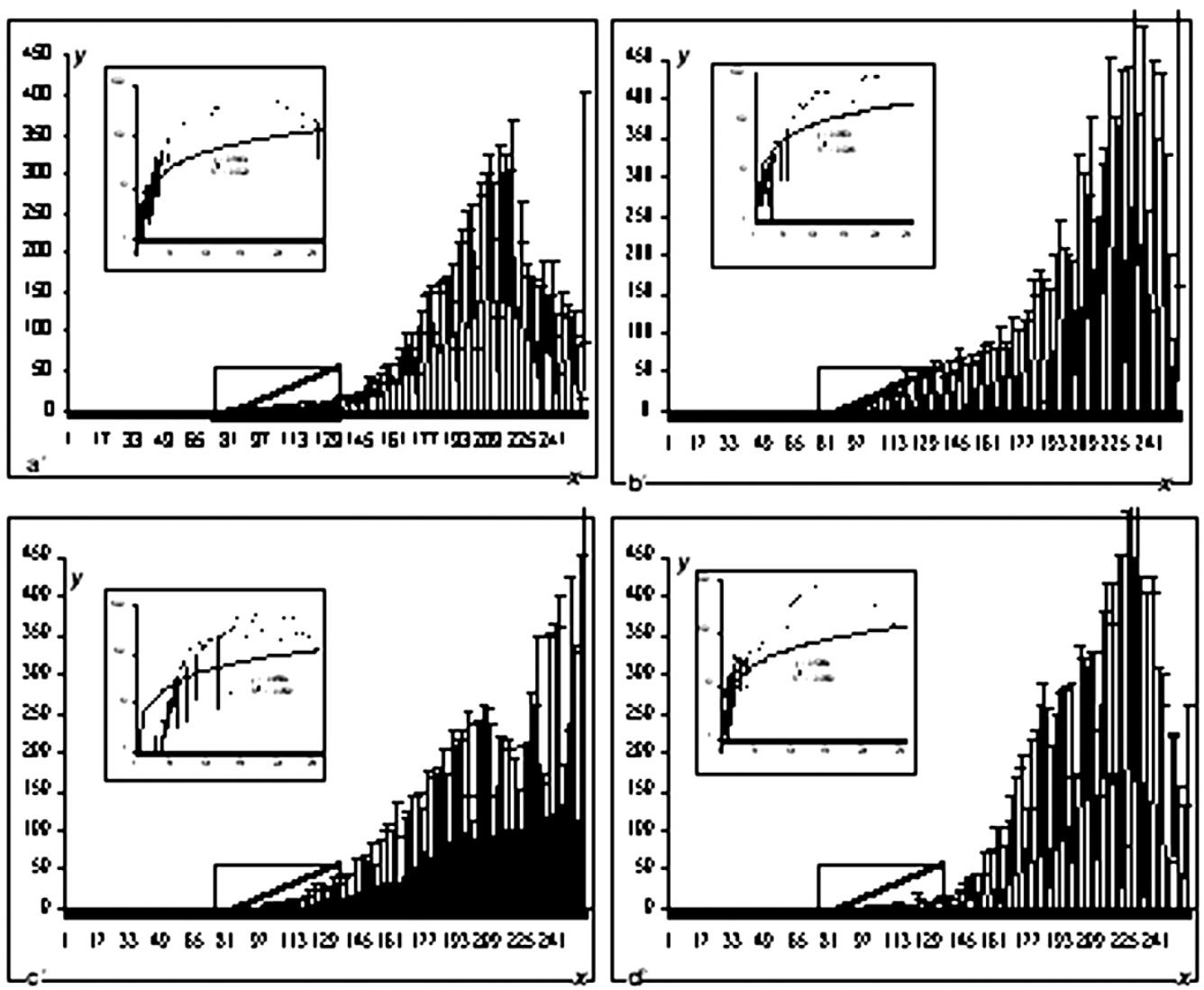

Fig.2 Gray-level histogram of 8-bit monochrome-digitized images of myoblasts monolayer showing the population distribution of the intensity of all the pixels comprising the image, among the 241 possible gray levels from black ( 0 , shown here at the extreme left edge of the histogram) to white (241 at the extreme right edge). a) Control (Con-tyr), b) Carbonated water (Car), c) Caffeine (Caf) d) Cola beverage (Glu). Central rectangle, between 81 and 129 shows the biggest change from lighter to darker tonalities. Proving the difference between control and treated samples.

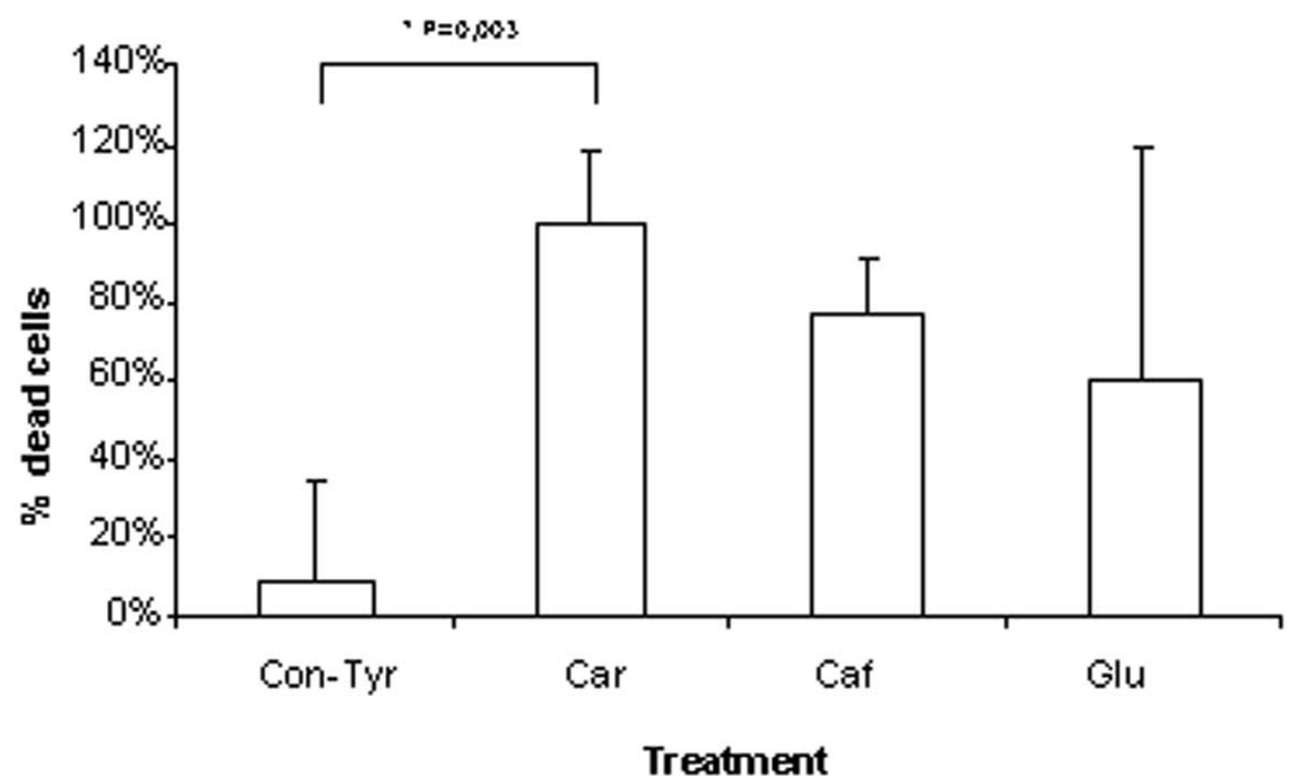

Fig. 3 Percentage of dead cells: Control tyrode's (ConTyr) $9 \%$, Club Soda water (Car) $98 \%$, Coffee (Caf-Tyr) $76,66 \%$ and Cola beverage (Car-Glu) 60\%. Values represent mean $\pm \mathrm{SE}$ $(\mathrm{n}=200) . * \mathrm{P}<0.05$. 

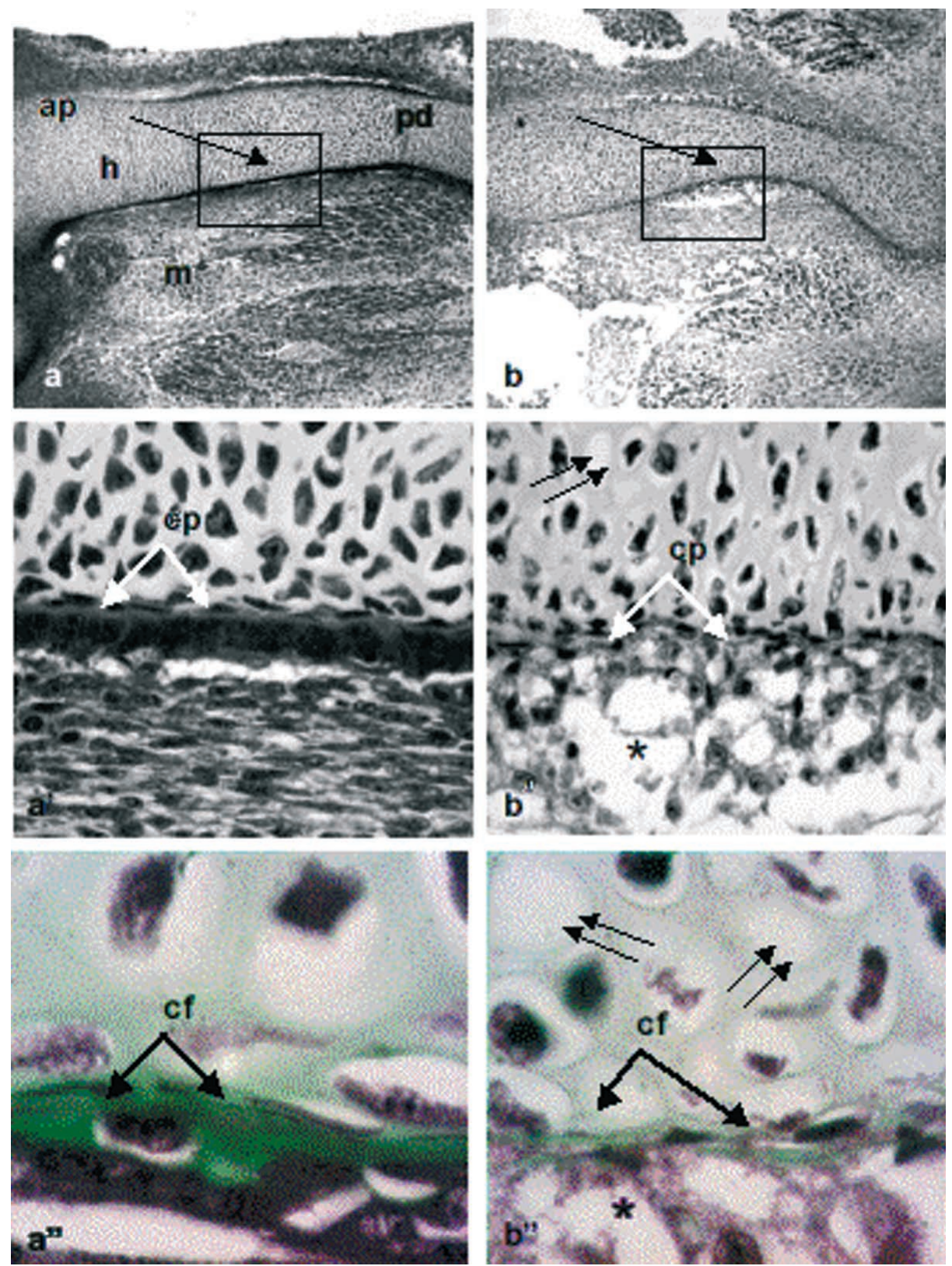

Fig. 4 Digital images captured with $20 \mathrm{x}(0,46 \mu \mathrm{m} \mathrm{x}$ pixels $)$ and $40 \times(0,23 \mu \mathrm{m} \times$ pixels $)$ in a $15 \mathrm{~mm} \times 15 \mathrm{~mm}$ tissue area of longitudinal section of lower limb of 8-day-old chick embryo. (a) Control: anteroposterior portion (ap), proximodistal portion (pd), hyaline cartilage portion (h) and skeletal muscle tissue (m), ( a') Calcium phosphate (cp) positive (white arrows) with Von Kossá stain (a") Collagen fiber (cf) positive (black arrows) with Gomori's Trichrome. (b) Longitudinal section of Soda Club treated lower limb of 8-day-old chicken embryo (b') empty lacunae (double arrow), (b") interfibrilar spaces (asterisk). located between the anteroposterior portion (ap) and the proximodistal portion (pd) of the limb (Fig. 4), is shown in representative pieces for the control (Fig. 4a) and for the treated (Fig. 4b). The intermediate portion is clear (arrow) and the hyaline portion $(\mathrm{h})$ and the muscular portion $(\mathrm{m})$. After zoomed in (box), the Control (Con-tyr) (Fig. 4a') shows the intermediate portion, Von Kossá reaction positive, strongly marked by a calcium phosphate precipitate strip (cp). It is also good to point out that it is visible, in the hyaline (h) control sample, a star-shaped chondrocytes population and the muscular portion $(\mathrm{m})$ looks as a compact organization that seems to be fibrillar and that is formed by a group of myoblasts arranged in parallel. Likewise it is worthy to mention the presence of collagen fibers (cf), positively stained with the Gomori's trichrome (Fig. 4a"). On the other hand, after the samples were treated with Soda Club (Car) the microarchitecture of the low limb presents the same organization (Fig. 4b'). However, in the hyaline portion (h) there are some empty lacunae, without chondrocytes (double arrow) and it is not as strongly marked with Von Kossá reaction as in the control sample. The muscular portion (m) looks disorganized with big interfibrilar spaces (asterisk). After zoomed in (Fig. 4b") we were able to see that the calcium phosphates precipitate strip (cp) was not there and 

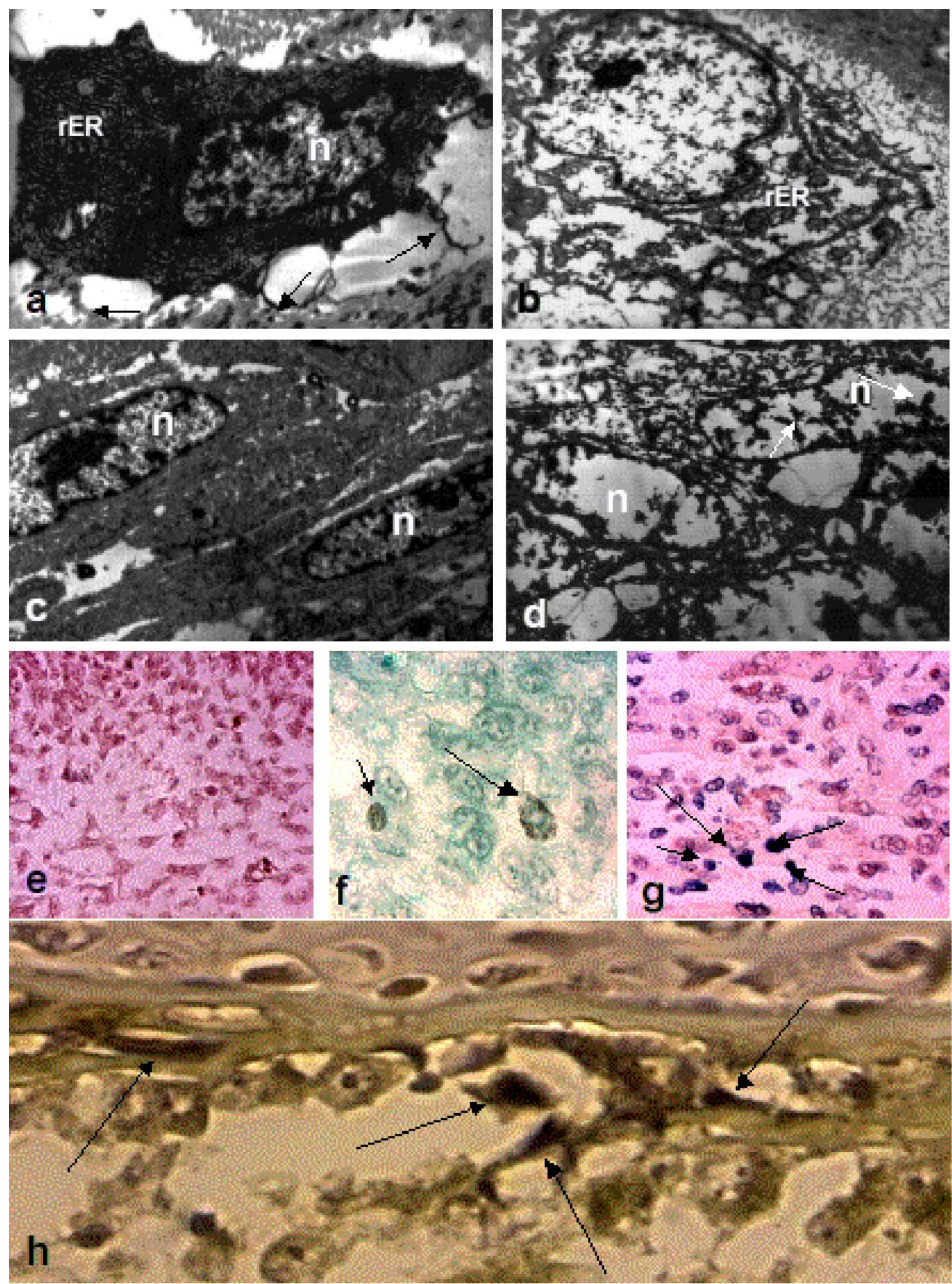

Fig. 5 Transmission Electron Micrographs (TEM) of chondrocytes (a,b) and skeletal muscle cells (c,d): control and treated respectively (7500X). Nuclei (n), thin cytoplasmic projections (black arrow), rough endoplasmic reticulum (rER), globular conglomerates (white arrows). Compared to control samples (e), the muscular disorganization was accompanied by a positive reaction of the apoptotic bodies on TACS (f), also a positive reaction to ApopTacg (g) and another positive reaction for the metalloproteases (h) in the inter fibrillar cartilage matrix (arrows). 
the positive staining with Gomori's trichrome staining was lower. The quantification of the surface area using the surrounding borders of the intermediate portions that had calcium phosphates (cp) and collagen (cf) showed the reduction of these elements. This response, to the calcium phosphate's (cp) precipitate strip is registered in a surface area of $4,731 \mu \mathrm{m}^{2}$ and $6.331 \mu \mathrm{m}^{2}$ for the collagen (cf). However, compared to control, in the intermediate portion of the Soda Club-treated samples (Car), the presence of the calcium phosphate's (cp) precipitates is reduced to an area of $0,183 \mu^{2}$, a significant difference of $96,13 \%$ less calcium phosphates (cp) than the control sample. The presence of collagen fibers (cf) is also reduced to a $1.080 \mu \mathrm{m}^{2}$ area. This change implies a significant variation of $82,92 \%$ less collagen (cf), in the intermediate portion of the low limbs treated with Soda Club. The ultrastructure (Fig. 5), reveals chondrocytes shaped as stars with thin cytoplasmic projections (arrow), nucleus (n) with disperse chromatin and basophilic cytoplasm with a granular appearance and plenty of rough endoplasmic reticulum (rER) distended and immersed in a thick cytoplasmic material (Fig. 5a). On the other hand, the samples treated with Soda Club (Car), (Fig. 5b), show a chondrocyte with a clear dissolution of the chromatin, loss of the nuclear and cytoplasmic content. Also the rough endoplasmic reticulum (rER) is disjointed. On the muscular portion of the control sample the nucleus of the myoblasts population were elongated (Fig. 5c). The elongated nucleus arranged in parallel is shown also with its nuclear material organized and its nucleolus.In contrast to control, the muscular tissue of the low limb treated with Soda Club (Car) (Fig. 5d), shows enlarged nucleus (n), of a higher size, with an evident loss of the parallel arrangement and clear disorganization of the nuclear material. The chromatin fragments are shown grouped in globular conglomerates (arrows) a thin granulation of the cytoplasmic content. Compared to control samples (Fig. 5e), the muscular disorganization was accompanied by a positive reaction of the apoptotic bodies on TACS (Fig. 5f), also a positive reaction to ApopTacg (Fig. 5g) and another positive reaction for the metalloproteases (Fig. 5h) in the inter fibrillar cartilage matrix (arrows).

\section{DISCUSSION}

In this paper it has been proved that carbonated water (Soda Club), induces the myotoxicity in the chicken embryo low limb. This myotoxicity was characterized by the simultaneous appearance of tissular and cellular reactions related to cell death processes by necrosis or apoptosis. In the apoptotic cell death the hypereosinophilia and the cytoplasmic receding with nuclear fragmentation are predominant characteristics (Yuan \& Horvitz, 2004). There was no inflammatory response, the cellular surface takes a vesicular aspect, the cellular volume is reduced and the proteases activation is included (Samali et al., 1996). Among the proteases, the metalloproteases of the extracellular matrix are enzymes that as main function they degrade the cartilage and the collagen when this becomes a homotoxine. Besides, once the proteases are free in the intercellular environment they act over the collagen fibers and generate the destruction of the collagen webs, its degradation and the loss of other components of the matrix. It also generates cell death (Herouy, 2001). The response of the connective tissue to the action of the carbonated water implies the alteration of the extracellular matrix. This was shown in this paper through the loss of the collagen matrix linked to the activation of metalloproteinases MPP1. These metalloproteinases degrade abnormal collagen produced by the polymerization of the extracellular matrix. This response allows us to define the connective tissue as a target of the carbonated water action. Different from apoptosis, necrosis is characterized by progressive destruction and irreversible damage in the cellular structure and subsequent definitive alteration of its normal functions (Syntichaki \& Tavermarakis, 2002). The cells are swollen, with a higher cellular volume and the subcellular organels disjointed losing their structure due to membrane fracture (Leist \& Jäättelä, 2001). The hipereosinophilia, the presence of apoptotic bodies, the disarticulation of the rough endoplasmic reticulum (rER), and also the activation of the metalloproteinases shown in this paper match the characteristics of both cell death processes, all this is show that carbonated water could, indeed, induce necroapoptosis as a possible toxic action mechanism. The simultaneous appearance of cellular injuries as the ones described "in vitro" and "ex vivo" and evaluated in a ultrastructural and inmunohistochemical level lead us to think of the possibility that this processes coexist as a consequence of the action carbonated water on the chicken embryo low limb. This coexistence has been defined as necroapoptosis (Lemasters, 1999). The later has also been described in other tissular damage situations due to isquemia/ repercussion phenomena, or induced by other chemical agents or viral agents (Kroemer et al., 1998). It is noteworthy to mention that a drink as Club Soda, used in this investigation, contains among its elements simple carbonates of fast metabolism and caffeine. Caffeine, among others, stimulates the skeletal musculature. Besides it has an $3.4 \mathrm{pH}$ so the acidification of the environment defines its acidity as a modulatory factor of the ionic equilibrium and particularly of the calcium ionic equilibrium. The acidity of the carbonated water induces the demineralization of the dentin and the collapse of the collagen matrix (Muerman et al., 1991) This property of the carbonated water may explain, in part, the possible origin of the tissular damage signs shown 
in this paper, since the responses obtained with the individual elements such as caffeine and glucose did not result significant. A possible cause related to myotoxic damage induced by carbonated water could be linked to the loss of the intracellular calcium control (Trump \& Berezky, 1992). The changes on the absorption of this ion, due probably to the calcium intake mechanism alterations, would be a probable way on the induction of the myotoxic damage. An evidence of this is the reduction of elements such as calcium phosphates in the extracellular matrix of the intermediate area between the hyaline and muscular portion. We can conclude, in an experimental level, that artificially carbonated water generates disequilibrium of the extracellular calcium which endangers the tissular micro-architecture of the low limb through the activation of a combined process of cell death such as necroapoptosis.

ACKNOWLEDGEMENTS. We are greatly indebted to the Consejo de Desarrollo Científico y Humanístico (CDCH$\mathrm{UCV}$ ) for their support with the project No PI-09-00-60112005 and to Miss Isabel Matos for the discussion of the final English version of this paper.

ÁLVAREZ, M. \& PERDOMO, L. Agua carbonatada y la muerte celular por necro-apoptosis en miembro inferior de embrión de pollo. Int. J. Morphol., 27(2):317-325, 2009.

RESUMEN: El agua carbonatada constituye una parte fundamental en muchas bebidas y su efecto ha sido estudiado en muchas situaciones patológicas. Sin embargo, el daño celular y de tejido como consecuencia del agua carbonatada no ha sido claramente investigado. El presente trabajo evalúa el efecto agudo in vitro de la soda sobre mioblastos obtenidos por cultivos en gota pendiente y el efecto sobre tejido muscular esquelético in vivo del miembro inferior de pollo de 8 días de desarrollo. Cuatro grupos de embriones fueron seleccionados al azar: a) Control (Con-tyr), b) Agua Carbonatada o Soda Club (Car), c) Café (Caf) y d) Bebida de cola (Glu). Las muestras fueron observadas por microscopía de luz. El análisis de imágenes digitales fue realizado. La ultraestructura del tejido control y tratado fue observada con Microscopía Electrónica de Transmisión (MET). La determinación de apoptosis fue realizada a través de TUNEL y 1 TACS Blue Label. La actividad de metaloproteasa MMP-1 fue ensayada. La población de mioblastos tratados con Soda Club mostró un elevado número de elementos eosinofílicos interpretado como un elevado número de células muertas, a diferencia del control y el grupo tratado con cafeína y bebida de Cola. En el tejido muscular se determinó una reducción de fosfatos de calcio y fibras de colágeno en una proporción de 53,86 \% y 82,95 \% respectivamente, acompañada por un desarreglo de las fibras y núcleos fragmentados, con reacción positiva para cuerpos apoptóticos y metaloproteasas en la matriz interfibrilar. Los resultados sugieren que el efecto tóxico del agua carbonatada sobre células y tejido pudiera estar vinculado con procesos combinados de muerte celular como necro-apoptosis. Se sugiere una mayor exploración de los eventos moleculares para dilucidar la combinación de los procesos de muerte celular sugerida en el presente trabajo.

PALABRAS CLAVE: Agua carbonatada; Embrión de pollo; Miembro inferior; Apoptosis; Necrosis.

\section{REFERENCES}

Alvarez, M.; Urbina,G.; Müller, C. \& Perdomo, L. Excretion products of Shigella dysenteriae and apoptotic cell death on chick embryo muscle tissue. Int. J. Morphol., 25(3):615-20, 2007.

Borrelli, J. Jr. Chondrocyte Apoptosis and Posttraumatic Arthrosis. J. Orthop. Trauma., 20(10):726-47, 2006.

Costouros, J. G.; Dang, A. C. \& Kim, H. T. Comparison of chondrocytes apoptosis in vivo and in vitro following acute osteochondral injury. J. Orthop. Res., 22(3):67883, 2004.

García, R. M.; Bueno, G. G.; Gonzalez, G. J. \& Carbajo, V. M. Digital slides in Pathologgy Deparments (I). A review of basic aspects in digital imaging. Rev. Esp. Pathol., 38(2):69-77, 2005.
Hamburger, V. \& Hamilton, H. A series of normal stages in development of chick embryo. Dev. Dyn., 195(4):23172, 1992.

Harding, M. Dental erosion in 5-year-old Irish school children and associated factors: a pilot study. Community Dent. Health., 20(3):165-70, 2003.

Herouy, Y. Matrix metalloproteinase in skin pathology. Int. J. Mol. Med., 7(1):3-12, 2001.

Kroemer, G.; Dallaporta, B. \& Resche-Rigon, M. The mitochondrial death/life regulador in apoptosis and necrosis. Anпu. Rev. Physiol., 60:619-42, 1998.

Leist, M. \& Jäättelä, M. Four deaths and a funeral: from caspases to alternative mechanisms. Nat. Rev. Mol. Cell Biol., 2:589-98, 2001. 
Lemasters, J. Mechanisms of hepatic toxicity. Necrapoptosis and the mitochondrial permeability transition: shared pathways to necrosis and apoptosis. Am. J. Physiol., 276:30-9, 1999.

Meurman, J. H.; Drysdale, T. \& Frank, R. M. Experimental erosion of dentin. Scand. J. Dent. Res., 99(6):457-62, 1991.

Morel, V.; Beruto, C. \& Quinn, T. M. Effects of Damage in the articular surface on the cartilage response to injurious compression in vitro. J. Biomech., 39(5):924-30, 2006.

Samali, A.; Gorman, A. \& Cotter, T. Apoptosis the story so far. Experientia, 52(10-11):933-41, 1996.

Shotton, M. D. Image resolution and digital image processing in electronic light microscopy. In: Cell Biology: A laboratory handbook. Second edition. Vol 3. Amsterdam, Academic Press, 1998. pp.85-98.

Syntichaki, P. \& Tavermarakis, N. Death by necrosis: uncontrollable catastrophe, or there is order behind the chaos? EMBO Rep., 3(7):604-9, 2002.

Trump, F. \& Berezky, K. I. Cellular and molecular basic of toxic cell in injury. In Cardiovascular Toxicology. 6th. Ed. New York, Daniel Acosta Jr and Horning-Raven Press, 1992.

Wyshak, G. \& Frisch, R. Carbonated beverages, dietary calcium, the dietary calcium/phosphorus ratio and bone fractures in the girls and boys. J. Adolecs. Health., 15(3):210-5, 1994.

Wyshak, G. Teenaged girls, carbonated beverage consumption, and bone fractures. Arch. Pediatr. Adolecs. Med., 154(6):610-3, 2000.

Yuan, J. \& Horvitz, H. R. A first insight into the molecular mechanisms of apoptosis. Cell, 116(2):S53-6, 2004.
Correspondence to:

Dr. Marco Álvarez

Instituto Anatómico José Izquierdo

Facultad de Medicina

Universidad Central de Venezuela

VENEZUELA.

Phone: 0212-605-3439

Fax: $\quad 0212-605-3449$

Email: marco.alvarez@med.ucv.ve

Received: 18-11-2008

Accepted: 20-01-2009 
